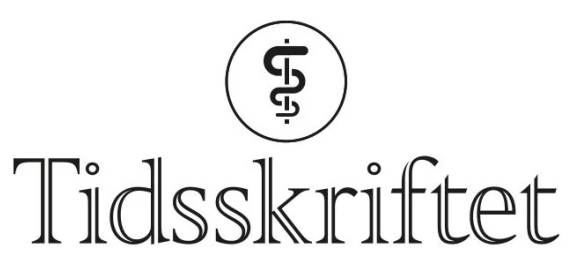

DEN NORSKE LEGEFORENING

\title{
I seng med seg!
}

\author{
TIDLIGERE I TIDSSKRIFTET
}

\section{ANNE KVEIM LIE}

Email:a.h.k.lie@medisin.uio.no

Tidsskriftet

I 1985 begynte man med bilder på forsiden av Tidsskriftet. Øivind Larsen var ansvarlig for bildevalg og forsidetekst inntil den nye designmessige omlegging kom i 2003 (11). Det var en stor oppgave, som Larsen løste med stor variasjon i bildebruk og tematikk (2). Ofte omhandlet både bilde og tekst et historisk tema, og ikke sjelden ble teksten avsluttet med en personlig vinkling - som her (Tidsskr Nor Lægeforen 1997; 117: 4055). 


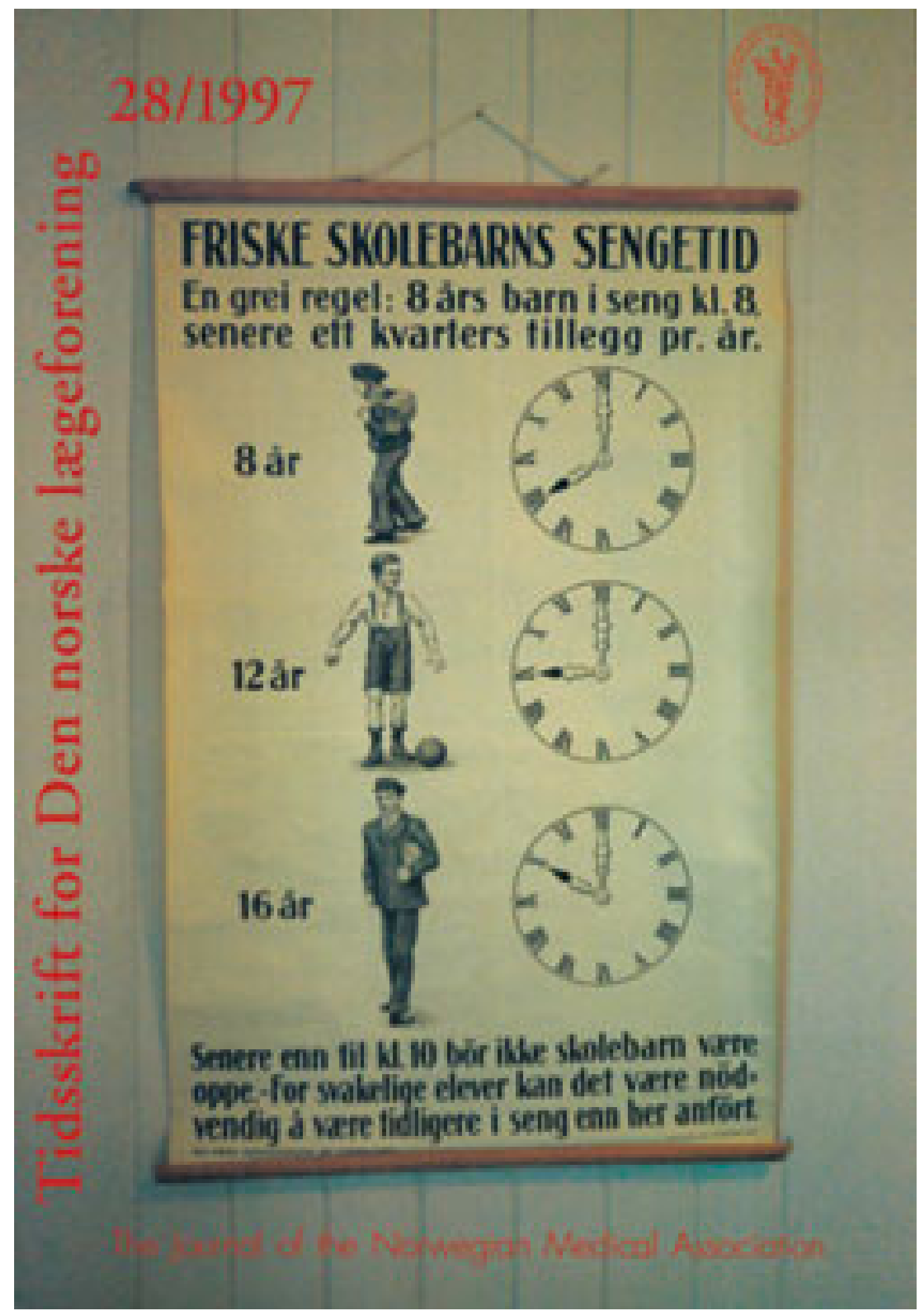

\section{Klokken åtte, åtte år...}

På skolemuseet, Stein skole, Vormsund i Akershus henger plakaten som er gjengitt på forsidebildet. Den er utgitt av Den norske nationalforening mot tuberkulosen og representerer et ganske godt eksempel på mellomkrigstidens store tro på orden, oppdragelse og «oppfostring» $\mathrm{i}$ helsearbeidet.

F.eks. er hygieneprofessor Carl Schiøtz' (1877-1938) store lærebok i hygiene fra 1937 stort sett meget normativ, også på dette punkt. Schiøtz går imidlertid enda lenger enn plakaten. Åtteårsregelen for sengetid gjelder fremtil klokken halv ti, skriver Schiøtz, for senere bør skoleelever ikke legge seg. Det har nemlig vist seg at det særlig er de eldre skolebarna som får altfor lite søvn, skriver han. 
I det hele blir man slått av i hvor stor grad hensynet til helse ble brukt som argument i oppdragelsen. Det sier seg selv at i en tid med mye sykdom, også blant barn, var dette nærliggende. Frykten for sykdom bidrog nok også til gjennomslagskraften.

Men overgangen til det alminnelig disiplinerende var uklar, f.eks. hva angikk sunt kosthold og det å sitte pent ved bordet. Eller hensiktsmessig klesdrakt og det å «ikke storme inn i stuen, uten å ta av deg luen». I hvilken grad de hygieniske oppdragelsesråd vitterlig også ble fulgt av barn, unge og foreldre rundt om i kongeriket i samtiden, har jeg ikke sett noen tall for. Så vi vet vel egentlig ikke hvordan effekten var.

Men hvis jeg i våre dager skulle skrevet normativt om leggetid, slik som Schiøtz gjorde, ville jeg heller utvidet skalaen. Tenk om alle 2o-åringer lå pent og sov i sengene sine klokken elleve ...

\section{LITTERATUR}

1. Herzberg AG. De lyse, de grønne, de fargerike. Tidsskr Nor Lægeforen 2006; 126: 16-7.

2. Nylenna M. Tidsskriftets forsider. Tidsskr Nor Lægeforen 1998; 118: 4724-8.

Publisert: 10. september 2009. Tidsskr Nor Legeforen. DOI: 10.4045/tidsskr.09.0741

(C) Tidsskrift for Den norske legeforening 2023. Lastet ned fra tidsskriftet.no 26. april 2023. 